\title{
TIME-ACTIVITY BUDGETS OF HARLEQUIN DUCKS MOLTING IN THE GANNET ISLANDS, LABRADOR
}

\author{
Author(s): Peter A. Adams, Gregory J. Robertson, Ian L. Jones
}

Source: The Condor, 102(3):703-708. 2000.

Published By: Cooper Ornithological Society

DOI: http://dx.doi.org/10.1650/0010-5422(2000)102[0703:TABOHD]2.0.CO;2

URL: http://www.bioone.org/doi/full/10.1650/0010-5422\%282000\%29102\%5B0703\%3ATABOHD

$\% 5 \mathrm{D} 2.0 . \mathrm{CO} \% 3 \mathrm{~B} 2$

BioOne (www.bioone.org) is a nonprofit, online aggregation of core research in the biological, ecological, and environmental sciences. BioOne provides a sustainable online platform for over 170 journals and books published by nonprofit societies, associations, museums, institutions, and presses.

Your use of this PDF, the BioOne Web site, and all posted and associated content indicates your acceptance of BioOne's Terms of Use, available at www.bioone.org/page/terms_of_use.

Usage of BioOne content is strictly limited to personal, educational, and non-commercial use. Commercial inquiries or rights and permissions requests should be directed to the individual publisher as copyright holder. 


\title{
TIME-ACTIVITY BUDGETS OF HARLEQUIN DUCKS MOLTING IN THE GANNET ISLANDS, LABRADOR ${ }^{1}$
}

\author{
Peter A. AdAms \\ Atlantic Cooperative Wildlife Ecology Research Network (ACWERN), Department of Biology, \\ Memorial University of Newfoundland, St. John's, NF, AlB 3X9, Canada \\ GREGORY J. RoBERTSON ${ }^{2}$ \\ Canadian Wildlife Service, 6 Bruce Street, Mount Pearl, NF, A1N 4T3, Canada
}

IAN L. JONES

Atlantic Cooperative Wildlife Ecology Research Network (ACWERN), Department of Biology, Memorial University of Newfoundland, St. John's, NF, AlB 3X9, Canada

\begin{abstract}
We studied the time-activity budgets of Harlequin Ducks (Histrionicus histrionicus) molting at the Gannet Islands, Labrador in the summer of 1998. For the entire population, a large proportion of time was spent hauled out of the water $(61.4 \%)$, and resting $(53.5 \%)$. Only a small proportion of time was spent foraging $(11.6 \%)$. Male Harlequin Ducks undergoing the pre-basic molt were hauled out of the water significantly more $(92.2 \%)$ than males in basic plumage $(8.1 \%)$. Males undergoing the pre-basic body feather molt foraged significantly less $(1.7 \%)$ than males in basic plumage (17.7\%). Harlequin Ducks do not appear to increase their food intake to meet the nutritional requirements of molt. Instead they may try to reduce thermoregulatory and maintenance costs by engaging in activities that do not consume much energy, and by staying out of cold water while their plumage is not intact. Furthermore, they may deliberately lose body mass while molting to regain the ability to fly at an earlier stage of wing molt.
\end{abstract}

Key words: foraging, Harlequin Ducks, Histrionicus histrionicus, molt, thermoregulation, time-activity budgets.

Both sexes of holarctic Anatidae undergo a synchronous and complete molt of their remiges and become flightless for a period of several weeks after breeding (Hohman et al. 1992). Many of these species migrate to molting areas different from their breeding or wintering grounds; these areas are expected to provide sufficient food supplies and be safe from predation (Salomonsen 1968, Hohman et al. 1992). The amount of time that waterfowl devote to major activities can provide insights into their requirements and constraints acting upon them. Studies demonstrate that the amount of time each individual allocates to certain behaviors is influenced by its condition, social status, and the environmental conditions of the area (Paulus 1988). Molting is a risky activity because the period of flightlessness increases their vulnerability to predation (Hohman et al. 1992). Molt also may be energetically

\footnotetext{
${ }^{1}$ Received 5 May 1999. Accepted 13 January 2000.

${ }^{2}$ Corresponding author. E-mail: greg.robertson@ec. gc.ca
}

costly because nutrients are required for the regrowth of feathers (Hohman et al. 1992). Therefore, time-activity budgets recorded at this time of the season can provide insights into the pressures faced by molting waterfowl (DuBowy 1985, Paulus 1988). Nevertheless, the behavioral ecology of molting waterfowl is generally poorly known, as many species are secretive at this stage and molt in inaccessible locations (Hohman et al. 1992).

We chose to study the Harlequin Duck (Histrionicus histrionicus) because they are accessible and easily observed while they molt (Robertson et al. 1997). Harlequin Ducks breed on fast flowing rivers and streams and winter along rocky coastlines (Robertson and Goudie 1999). The coast of Labrador is known to be an important molting area for Harlequin Ducks in eastern North America (Robertson and Goudie 1999). The eastern North American population of Harlequin Ducks is listed as endangered in Canada and current estimates place the population at about 1,500 individuals (Goudie 1991; Harlequin Duck Recovery Team, unpubl. data). Harlequin Ducks migrate to coastal molting areas after breeding and these areas may be the same or different than those used for wintering. Upon arriving at the coast, males immediately begin the pre-basic body feather molt, in which they lose their showy breeding plumage (alternate plumage) and acquire a drab female-like plumage (basic or eclipse plumage). Subsequently, they molt their wing and tail feathers; nonbreeding females also molt their wing and tail feathers at this time. After regaining the ability to fly, males undergo the pre-alternate body feather molt and acquire a new alternate plumage (Robertson et al. 1997).

The aim of our study was to determine the pressures and constraints that molting Harlequin Ducks face by studying how they allocate their time to different activities during molt. The specific objectives of this study were to: (1) document the chronology of molting Harlequin Ducks at the Gannet Islands, (2) quantify time-activity budgets to: (a) make comparisons between the different stages of body molt and wing molt, (b) make comparisons between males and females, and (c) compare activity during the molt with other times of the year, and (3) compare the time-activity budgets of molting Harlequin Ducks with other species of waterfowl. 


\section{METHODS}

\section{STUDY SITE}

We studied Harlequin Duck activities during the summer (July and August) of 1998 at the Gannet Islands $\left(53^{\circ} 56^{\prime} \mathrm{N}, 56^{\circ} 32^{\prime} \mathrm{W}\right)$ located $50 \mathrm{~km}$ east of Cartwright, Labrador. This is a cluster of six offshore islands ranging in size from 4.4 to 125 ha. The Gannet Islands are low-lying, sparsely vegetated (grasses and dwarf shrubs) granite rocks, with a maximum height of $66 \mathrm{~m}$ above sea level (Birkhead and Nettleship 1995).

\section{TIME-ACTIVITY BUDGETS}

We recorded the activity budgets of Harlequin Ducks during three different time periods of the day: morning (07:00-12:00), afternoon (12:00-17:00), and evening (17:00-22:00). We made observations from three sites on one island, with observation bouts divided roughly equally and randomly in time and location. Birds were observed with a spotting scope or binoculars from 50 $200 \mathrm{~m}$ away. Observations were restricted to periods of good weather. We used a modified scan sample method to quantify time-activity budgets (Goudie and Ankney 1986). This involved a scan observation of a group of birds (five to eight maximum) within a flock for a total period of $5 \mathrm{~min}$ with activities of each individual recorded at 15 -sec intervals. Unlike a standard scan sample, we followed each individual and recorded its own behavior at each interval. If birds went out of sight at any time during the observation, the scan sample was not used.

Twenty separate behaviors were recorded during the study; these were pooled into six general categories (Gowans et al. 1997, Fischer 1998, Goudie 1999): foraging (including peering, feeding, diving, and pausing), rest (which includes loafing, sleeping, and resting), maintenance (including preening, scratching, stretching, and splash bathing), locomotion (including tail-wagging, walking, swimming, flying, wing-flapping, and scooting), social (agonistic and courtship), and alert (birds raising their heads and becoming still to scan the immediate area). In addition to the above categories, we recorded whether individuals were hauled out of the water. Before beginning to record a behavioral sample, birds were watched for a few minutes to establish whether birds on the water were engaged in a feeding bout (therefore pausing) or were simply resting.

The stage of body molt for each male was determined by close observation of their body plumage. We identified three categories of body feather molt, alternate (breeding) plumage, undergoing pre-basic body feather molt, and basic plumage for males (Robertson et al. 1997). The stage of wing molt was classified (old, shed, and regrowing) for males and females as the birds began to lose their wing feathers (remiges) (Robertson et al. 1997). The total population and molt stage of Harlequin Ducks at each observation area also was recorded during each focal-scan sample.

\section{STATISTICAL ANALYSES}

We pooled all of the behavioral records for each sex and molt class into daily means for analysis to reduce sample sizes to appropriate levels and avoid pseudoreplication. The number of individuals sampled each day ranged from 5 to 95 . To control for the possibility that changes in behavior were due to seasonal changes and not changes in molt class, we restricted specific comparisons to certain time periods. For the analysis of males undergoing body feather molt, we choose behavioral data from 13 to 31 July. These dates were selected because the males had yet to begin their wing molt. For the analysis of individuals undergoing wing molt (flying or flightless), we selected data from 26 July to the end of the study (27 August). We selected these days because males were finished with their body feather molt by this time. The same dates were chosen for comparisons between sexes.

The proportion of time allocated to different behaviors was analyzed with nonparametric statistics because no transformations were successful in normalizing the data. We used Kruskal-Wallis tests to determine whether there were differences in time-activity budgets between individuals (1) molting body plumage and those in basic plumage (males only) and (2) before and after wing feathers were shed. We also used this test to detect differences in time-activity budgets between sexes, before and after wing feathers were shed. Tests were considered significant at $P<0.05$, and all tests were two-tailed.

\section{RESULTS}

\section{MOLT CHRONOLOGY}

At the beginning of the study in mid-July, approximately half of the males were undergoing pre-basic body feather molt, the rest had completed this molt (Fig. 1). By early August, males had completed the pre-basic feather molt and some had shed their primaries. From 10 August to the end of the study (27 August), males were flightless (Fig. 1). A varying proportion of females were flightless throughout August, however, unlike males, at all observation periods some females could fly (Fig. 1).

\section{TIME-ACTIVITY BUDGETS}

For the entire population, a large proportion of time was spent hauled out of the water and resting, whereas only a minimal amount of time was spent foraging (Table 1). Males undergoing the pre-basic body feather molt were hauled out of the water significantly more often than males in basic plumage (Kruskal-Wallis, $H$ $=21.8, P<0.001)$. Males undergoing the pre-basic body feather molt spent significantly less time foraging $\left(H_{1}=9.8, P=0.002\right)$ and more time in locomotion $\left(H_{1}=6.4, P=0.01\right)$ than males in basic plumage The amount of time allocated to resting, maintenance, social, and alert behavior was not different $(P>0.10$; Table 1). Males undergoing the pre-basic body feather molt and males in basic plumage both allocated a large proportion of time to resting.

Males with their primaries maintained themselves more than those males that were flightless $\left(H_{1}=10.0\right.$, $P=0.002$; Table 1). Flightless males rested more than males able to fly $\left(H_{1}=4.7, P<0.05\right.$; Table 1$)$. The amount of time allocated to foraging was not different, nor was the amount of time hauled out (all $P>0.10$ ). Flightless females rested for a larger portion of the time than females able to fly $\left(H_{1}=4.0, P<0.05\right.$; Table 1). Also, flightless females allocated more time 

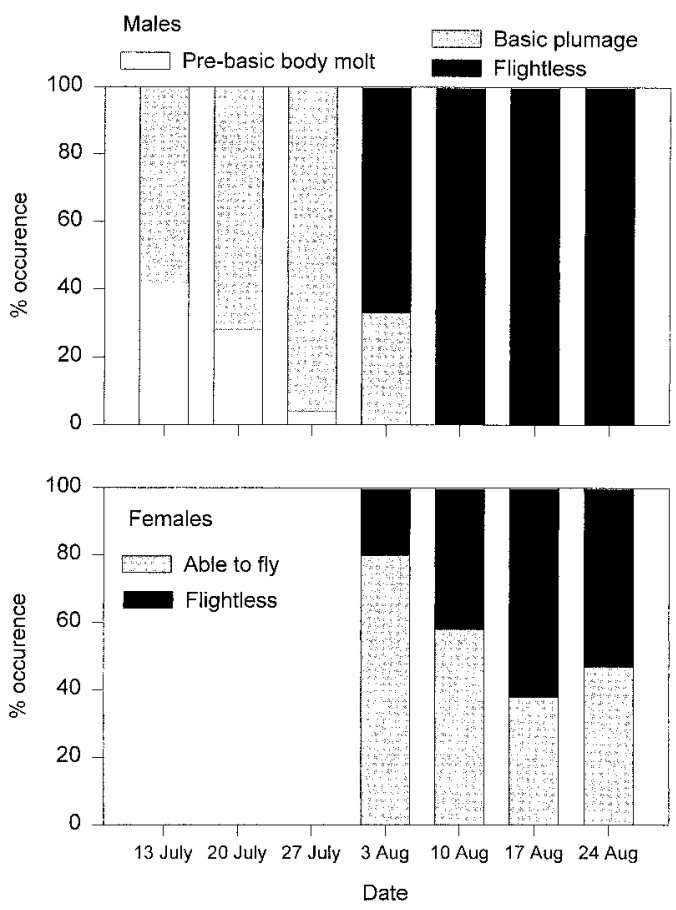

FIGURE 1. Molt chronology of Harlequin Ducks in the Gannet Islands, Labrador, 1998.

to alert behavior than flying females $\left(H_{1}=3.8, P<\right.$ 0.05; Table 1).

Although both sexes spent a small proportion of their time foraging during wing molt, females fed significantly less than males $\left(H_{1}=4.4, P<0.05\right)$. Females also devoted significantly less time to locomotion and social behaviors than males $\left(H_{1}=4.7\right.$, $P<0.05$ and $H_{1}=5.5, P<0.05$, respectively; Table 1). There was only one significant difference in time-activity budgets between males and females that could still fly: males spent significantly more time in maintenance behavior than did females $\left(H_{1}\right.$ $=3.8, P<0.05$; Table 1 ). Both sexes at this time spent a large proportion of their time hauled out and resting.

\section{DISCUSSION}

Harlequin Ducks molting at the Gannet Islands allocated only a minimal amount of time to foraging, whereas a large proportion of time was spent hauled out of the water and resting. The molt chronology was similar to a population in southwest British Columbia (Cooke et al. 1997). Furthermore, observations that all males were flightless for most of August while some females were still able to fly, also was the case in British Columbia (Cooke et al. 1997, Robertson et al. 1997). These observations suggest that some females are leaving the breeding streams throughout August and may molt their wing feathers in the Gannet Islands in September.
To meet their nutritional requirements, wintering Harlequin Ducks spend a considerable portion of their day foraging, varying between 51.0-77.5\% depending on the site, sex, and time of year (Goudie 1984, 1999, Fischer 1998). High foraging rates during winter are likely due to short day lengths and increased thermoregulatory costs due to low temperatures (Goudie and Ankney 1986). Harlequin Ducks on breeding streams spend between 7.0-55.9\% of daylight hours foraging, depending on the sex, location, and whether they were paired (summarized in Robertson and Goudie 1999). In general, these values are higher than our value of $11.6 \%$.

The amount of time Harlequin Ducks spent foraging was probably too low to provide the energy requirements for molt. Nutrients and energy beyond maintenance levels are required during molt (King and Murphy 1992); however, current evidence suggests that molt is not energetically stressful (Ankney 1979, King and Murphy 1985, Brown and Bryant 1996). Molting seaducks can take two possible approaches to meet these nutritional demands. They can reduce energyexpensive activity to a minimum so that most of their energy can be used for molting (Pehrsson 1987). Diving is an energetically costly activity in birds due to the effort needed to overcome buoyancy and due to heat loss (Bevan and Butler 1992, de Leeuw 1996). The other possible approach to meet the nutritional demands of molting would be to increase foraging behavior to a degree where more food is taken in than is being used up by the increased activity. It appears that the Harlequin Ducks in our study took the first approach and reduced the amount of time spent in energetically expensive activity.

Harlequin Ducks molting their body plumage probably experience decreased insulative and waterproofing capacity. When birds experience temperatures outside of their thermoneutral zone (i.e., below their lower critical temperature), their metabolic rate must increase to provide the required heat to maintain their body temperature (Alisauskas and Ankney 1992). Lower critical temperatures are higher for smaller birds because smaller birds have a higher surface area to volume ratio, and larger birds have a higher ratio of plumage mass to surface area (Calder 1974, Alisauskas and Ankney 1992).

Contact with water increases thermal conductance by a factor of 2.2 during swimming and by a factor of 4.8 during diving (de Vries and van Eerden 1995). Thermal conductivity increases even more (a factor of two) when the waterproofing capacity of the body plumage is deteriorated (de Vries and van Eerden 1995). The structure of the plumage is responsible for its waterproofing ability, and only functions properly when the entire plumage is intact (Rijke 1969). Aquatic birds can do one of three things to cope with this higher daily energy expenditure due to thermoregulatory costs (de Vries and van Eerden 1995). First, they can choose sites that have high ambient temperatures. Second, they can increase their intake of food to compensate for higher energetic demands. Last, they can spend little time in the water to reduce the energetic costs of thermoregulation (Brown and Bryant 1996). 
TABLE 1. Time-activity budgets of Harlequin Ducks molting at the Gannet Islands, Labrador, July and August, 1998

\begin{tabular}{|c|c|c|c|c|c|c|c|c|c|}
\hline \multirow[b]{2}{*}{ Sex } & \multirow[b]{2}{*}{ Molt stage } & \multirow[b]{2}{*}{$n^{\mathrm{a}}$} & \multicolumn{7}{|c|}{$\%$ of time } \\
\hline & & & $\begin{array}{c}\text { Hauled } \\
\text { out }\end{array}$ & Rest & Foraging & $\begin{array}{c}\text { Mainte- } \\
\text { nance }\end{array}$ & Locomotion & Alert & Social \\
\hline \multirow[t]{5}{*}{ Male } & Pre-basic ${ }^{b}$ & 14 & 92.2 & 60.0 & 1.7 & 33.5 & 4.1 & 0.6 & 0.3 \\
\hline & Basic $^{b}$ & 18 & 8.1 & 50.4 & 17.7 & 23.0 & 8.6 & 0.2 & 0.1 \\
\hline & Flying ${ }^{\mathrm{c}}$ & 11 & 78.4 & 40.5 & 9.5 & 40.4 & 9.1 & 0.1 & 0.0 \\
\hline & Flightless ${ }^{\mathrm{d}}$ & 22 & 64.1 & 62.2 & 13.1 & 17.1 & 6.8 & 0.2 & 0.1 \\
\hline & Mean & & 60.7 & 53.3 & 10.5 & 28.5 & 7.2 & 0.3 & 0.1 \\
\hline \multirow[t]{3}{*}{ Female } & Flying ${ }^{\mathrm{e}}$ & 27 & 58.7 & 43.8 & 16.6 & 24.7 & 14.3 & 0.0 & 0.0 \\
\hline & Flightless $^{\mathrm{d}}$ & 18 & 65.4 & 63.3 & 8.8 & 18.7 & 6.3 & 1.2 & 0.1 \\
\hline & Mean & & 62.1 & 53.6 & 12.7 & 21.7 & 10.3 & 0.6 & 0.1 \\
\hline
\end{tabular}

a Number of observation days

b Only observations between 13 July and 31 July.

' Observations from 26 July to the end of the study (includes all flying males in basic body plumage).

d Observations from 26 July to the end of the study (birds with shed and regrowing primaries pooled).

e Observations from 26 July to the end of the study.

It appears that male Harlequin Ducks molting their body plumage select the last option.

Unlike Harlequin Ducks, pre-flightless dabbling ducks spent a considerable portion of their time foraging (Paulus 1984, DuBowy 1985). When flightless, Canvasbacks (Aythya valisineria) spent less time foraging than birds in other stages of molt (Thompson 1992), whereas flightless King Eiders (Somateria spectabilis) and Lesser Scaup (Aythya affinis) foraged at an intensity similar to non-molting birds (Austin 1987, Frimer 1994). Many waterfowl species rely on their normal diet to meet the nutritional requirements of the molt (Ankney 1979, Bailey 1985, Thompson and Drobney 1997). Larger species and species that do not dive for food may be able to continue feeding through the molting period and still maintain a positive energy balance, whereas smaller diving species like Harlequin Ducks may not.

Males that retained old primaries maintained themselves (preened and scratched) more often than flightless males. Males that still retained their primaries had recently completed a body feather molt. As new body feathers grow in, they did so randomly and out-ofplace, and regular preening would serve to rearrange the plumage and reposition out-of-place feathers. Also, the uropygial gland secretes a rich oil of waxes, fat, fatty acids, and water, and regular application with the bill would help clean the body feathers and preserve their flexibility and moistness (Jacob 1978). Flightless male Harlequin Ducks spent more time resting than when able to fly. Some ducks feed less during the flightless period than during the pre-flightless period, which may be a strategy to reduce body mass and the flightless period (DuBowy 1985, Pehrsson 1987). Using up stored nutrients and staying relatively immobile may function to decrease vulnerability to predators (Pehrsson 1987). Females allocated more time to alert behavior while flightless than when they could fly. This may be an indication that these birds are aware of their vulnerability to predation while flightless and are more alert (Hohman et al. 1992).

There were few differences in the behavior of males and females. As seen in other studies (Gowans et al.
1997), males spent more time in social interactions than females, however, only a minimal amount of time was allocated to this behavior. Pairing occurs after molting, therefore intense social interaction is not expected (Cooke et al. 1997, Robertson et al. 1998). Males also tended to engage in maintenance behaviors more often, probably because they had just undergone an extensive body feather molt. In our study, flightless females fed less than males. Other studies on Harlequin Ducks (Fischer 1998), Common Goldeneye (Bucephala clangula) (Nilsson 1970), and Mallards (Anas platyrhynchos) (Pehrsson 1987) revealed that females forage more than males. Because females are slightly smaller, their strategy may be to forage less and haul out of cold water more. Females molting at this time of year are yearlings or failed breeders. These birds may have already accumulated significant nutrient reserves and did not need to forage as much as breeding males.

In summary, Harlequin Ducks molting at the Gannet Islands, Labrador behaved differently than recorded for this species at other coastal locations during the winter (Goudie 1984, 1999, Fischer 1998). The amount of time they allocated to foraging was much lower and they spent a large proportion of time hauled out of the water and resting. Due to their small body mass and being diving birds, they are expected to have high thermoregulatory costs and this cost is elevated when their plumage is incomplete. Molting Harlequin Ducks apparently conserved energy by reducing physiological activities that are energetically expensive (such as diving), and reducing contact with water, in order to meet the energy demands of molt. Harlequin Ducks may also reduce body mass during the molt to be able to regain the ability to fly as soon as possible.

We thank Mark Button, Brian Veitch, and Sabir Bin Muzaffar for their invaluable assistance and companionship in the field and Richard Elliot for encouraging us to undertake this study. Financial support was provided by an Atlantic Cooperative Wildlife Ecology Research Network CWS/NSERC Industrial Chair re- 
search grant to ILJ, and by the Canadian Wildlife Service, the Northern Scientific Training Program of the Department of Indian Affairs and Northern Development, and Memorial University of Newfoundland. We thank the Canadian Wildlife Service for permission to use their facilities on the Gannet Islands, and the Parks and Natural Areas Division, Department of Tourism, Culture and Recreation, province of Newfoundland and Labrador for permission to work on the Gannet Islands Seabird Ecological Reserve.

\section{LITERATURE CITED}

Alisauskas, R. T., And C. D. AnKney. 1992. The cost of egg-laying and its relation to nutrient reserves in waterfowl, p. 30-61. In B. D. J. Batt, A. D. Afton, M. G. Anderson, C. D. Ankney, D. H. Johnson, J. A. Kadlec, and G. L. Krapu [EDS.], Ecology and management of breeding waterfowl. Univ. Minnesota Press, Minneapolis, MN.

AnKNEY, C. D. 1979. Does the wing molt cause nutritional stress in Lesser Snow Geese? Auk 96:6872.

Austin, J. E. 1987. Activities of postbreeding Lesser Scaup in southwestern Manitoba. Wilson Bull. 99: 448-456.

BAILEY, R. O. 1985. Protein reserve dynamics in postbreeding adult male Redheads. Condor 87:23-32.

Bevan, R. M., AND P. J. Butler. 1992. The effects of temperature on the oxygen consumption, heart rate and deep body temperature during diving in the Tufted Duck (Aythya fuligula). J. Exp. Biol. 163:139-151.

BiRkHEAD, T. R., AND D. N. Nettleship. 1995. Arctic fox influence in a seabird community in Labrador: a natural experiment. Wilson Bull. 107:397-412.

Brown, C. R., AND D. M. BRyant. 1996. Energy expenditure during molt in Dippers (Cinclus cinclus): no evidence of elevated costs. Physiol. Zool. 65:1036-1056.

CAlder, W. A., III. 1974. Consequences of body size for avian energetics, p. 86-144. In R. A. Paynter [ED.], Avian energetics. Publ. Nuttall Ornithol. Club 15.

Cooke, F., G. J. Robertson, R. I. Goudie, and W. S. BoyD. 1997. Molt and the basic plumage of male Harlequin Ducks. Condor 99:83-90.

DE LEEUW, J. J. 1996. Diving costs as a component of daily energy budgets of aquatic birds and mammals: generalizing the inclusion of dive-recovery costs demonstrated in Tufted Ducks. Can. J. Zool. $74: 2131-2142$.

de VRIeS, J., AND M. R. VAn EERden. 1995. Thermal conductance in aquatic birds in relation to the degree of water contact, body mass, and body fat: energetic implications of living in a strong cooling environment. Physiol. Zool. 68:1143-1163.

DuBowy, P. J. 1985. Feeding ecology and behaviour of postbreeding male Blue-winged Teal and Northern Shovelers. Can. J. Zool. 63:1292-1297.

Fischer, J. B. 1998. Feeding behaviour, body condition, and oil contamination of wintering Harlequin Ducks (Histrionicus histrionicus) at Shemya Island, Alaska. M.Sc. thesis, Univ. Massachusetts, Amherst, MA.
FrIMER, O. 1994. The behaviour of moulting King Eiders Somateria spectabilis. Wildfowl 45:176-187.

Goudie, R. I. 1984. Comparative ecology of Common Eiders, Black Scoters, Oldsquaws, and Harlequin Ducks wintering in southeastern Newfoundland. M.Sc. thesis, Univ. Western Ontario, London, Ontario, Canada.

GoudIE, R. I. 1991. The status of the Harlequin Duck (Histrionicus histrionicus) in eastern North America. Committee on the Status of Endangered Wildlife in Canada (COSEWIC), Ottawa, Ontario, Canada.

GoudIE, R. I. 1999. Behaviour of Harlequin Ducks and three species of scoters wintering in the Queen Charlotte Islands, British Columbia, p. 6-13. In R. I. Goudie, M. R. Petersen, and G. J. Robertson [EDS.], Behaviour and ecology of sea ducks. Canadian Wildl. Serv. Occ. Pap. No. 100, Ottawa, Ontario, Canada.

Goudie, R. I., And C. D. Ankney. 1986. Body size, activity budgets, and diets of sea ducks wintering in Newfoundland. Ecology 67:1475-1482.

Gowans, B., G. J. Robertson, And F. Cooke. 1997. Behaviour and chronology of pair formation by Harlequin Ducks Histrionicus histrionicus. Wildfowl 48:135-146.

Hohman, W. L., C. D. Ankney, and D. H. Gordon. 1992. Ecology and management of postbreeding waterfowl, p. 128-189. In B. D. J. Batt, A. D. Afton, M. G. Anderson, C. D. Ankney, D. H. Johnson, J. A. Kadlec, and G. L. Krapu [EDS.], Ecology and management of breeding waterfowl. Univ. Minnesota Press, Minneapolis, MN.

JАСОВ, J. 1978. Uropygial gland secretions and feather waxes. Chem. Zool. 10:165-211.

King, J. R., AND M. E. MurPhy. 1985. Periods of nutritional stress in the annual cycles of endotherms: fact or fiction? Am. Zool. 25:955-964.

King, J. R., AND M. E. MurPhy. 1992. Energy and nutrient use during moult by White-crowned Sparrow Zonotrichia leucophrys gambelii. Ornis Scand. 23:304-313.

NiLSSON, L. 1970. Food-seeking activity of south Swedish diving ducks in the nonbreeding season. Oikos 21:145-154.

Paulus, S. L. 1984. Activity budgets of nonbreeding Gadwalls in Louisiana. J. Wildl. Manage. 48:371380 .

Paulus, S. L. 1988. Time-activity budgets of nonbreeding Anatidae: a review, p. 135-152. In M. W. Weller [ED.], Waterfowl in winter. Univ. Minnesota Press, Minneapolis, MN.

Pehrsson, O. 1987. Effects of body condition on molting in Mallards. Condor 89:329-339.

RIJKE, A. M. 1969. Wettability and phylogenetic development of feather structure in water birds. J. Exp. Biol. 52:469-479.

Robertson, G. J., F. Cooke, R. I. Goudie, And W. S. BOYD. 1997. The timing of arrival and moult chronology of Harlequin Ducks Histrionicus histrionicus. Wildfowl 48:147-155.

Robertson, G. J., F. Cooke, R. I. Goudie, And W. S. BoYD. 1998. The timing of pair formation in Harlequin Ducks. Condor 100:551-555. 
Robertson, G. J., AND R. I. Goudie. 1999. Harlequin Duck (Histrionicus histrionicus). In F. Gill and A. Poole [EDS.], The birds of North America, No. 466. Birds of North America, Inc., Philadelphia, PA.

SAlomonsen, F. 1968. The molt migration. Wildfowl 19:5-24.
Thompson, J. E. 1992. The nutritional ecology of molting male Canvasbacks (Aythya valisineria) in central Alberta. M.Sc. thesis, Univ. Missouri, Columbia, MO.

Thompson, J. E., AND R. D. Drobney. 1997. Diet and nutrition of male Canvasbacks during postreproductive molts. J. Wildl. Manage. 61:426-434.

\title{
RELATIONSHIP BETWEEN TAIL COLOR PATTERN AND REPRODUCTIVE SUCCESS, MATE ACQUISITION AND NEST PREDATION IN RUFOUS BUSH CHATS ${ }^{1}$
}

\author{
Fernando Alvarez \\ Estación Biológica de Doñana, C.S.I.C., Apartado postal 1056, E-41080 Sevilla, Spain, \\ e-mail: alvarez@.ebd.csic.es
}

\begin{abstract}
Rufous Bush Chats (Cercotrichas galactotes) show a conspicuous tail color pattern consisting of terminal white and subterminal black patches which are shown in tail display during nest defense, aggression, and courtship. Multiple linear regression of visual tail features of males showed that in the two years of study, birds with higher bilateral symmetry in the black patches attained higher seasonal reproductive success, mated earlier in the season, and their nests were less likely to be depredated. In one year, birds with greater white terminal patches also attained higher reproductive success and their nests were less likely to be depredated, and in the other year birds with longer tails paired earlier. I suggest that these tail features have an effect on reproductive success by facilitating early pairing and/or by diminishing nest predation.
\end{abstract}

Key words: Cercotrichas galactotes, distraction displays, mate acquisition, reproductive success, $R u$ fous Bush Chats, tail color pattern.

Male plumage color pattern in passerines has an effect on reproduction, either through female choice (Andersson 1994) and male contest competition (Pärt and Qvarnström 1997), or as a result of distraction displays towards potential predators during nest defense (Baker and Parker 1979).

The visual features affecting reproduction often are situated in the tail, which is displayed towards recipients. Visual tail features may consist of tail length (Andersson 1982, Møller 1988, Barnard 1990), symmetry of tail feathers (Møller 1992), tail damage (Fitzpatrick and Price 1997), or size of tail spots (Kose and Møller 1999).

During nest defense, antagonistic interactions, and courtship, Rufous Bush Chats (Cercotrichas galacto2000. tes) cock their tail and move it up and down, either closed or more or less spread, sometimes accompanied with a simultaneous jerking of both wings (López 1983, Cramp 1988, Keith et al. 1992). In this way the characteristics of the conspicuous terminal white patches and adjacent black patches of the rust-colored tail feathers are shown (Fig. 1).

When chicks are found in the nest, and apparently more often as they grow older, or when a potential predator approaches the nest too closely, parent Rufous Bush Chats use a tactic of distraction (Cramp 1988), approaching the potential predator and flying away from it and from the nest, tail displaying while facing the predator, sometimes at less than $1 \mathrm{~m}$. At a distance, the birds are usually not distinct from the background, to become visible when displaying the conspicuous tail pattern.

Although the birds display towards any kind of predator, including humans (pers. observ.), of all potential nest predators in the study area, the Common Cuckoo (Cuculus canorus) is the only species with sufficient visual acuity to pay special attention to color patterns, commonly parasitizing (average of $27 \%$ of nests, Alvarez 1994a) and depredating (Alvarez 1994b) Rufous Bush Chat nests.

In aggressive situations, tail display (also while facing the opponent) usually accompanies threats, chases, and attacks. During courtship, it accompanies approaches, chases, and copulation attempts by the male, and the male displays either facing towards or away from the recipient female (the pattern is visible from both sides of the tail feathers) (Cramp 1988).

Rufous Bush Chats arrive to their breeding quarters in southern Spain during April and early May and remain until August and September (pers. observ.). Males arrive before females, establish mating territories which are often found in vineyard fields, and they sing from fixed posts (Cramp 1988, Alvarez 1996, 1997). Both sexes build a nest, but only the female 


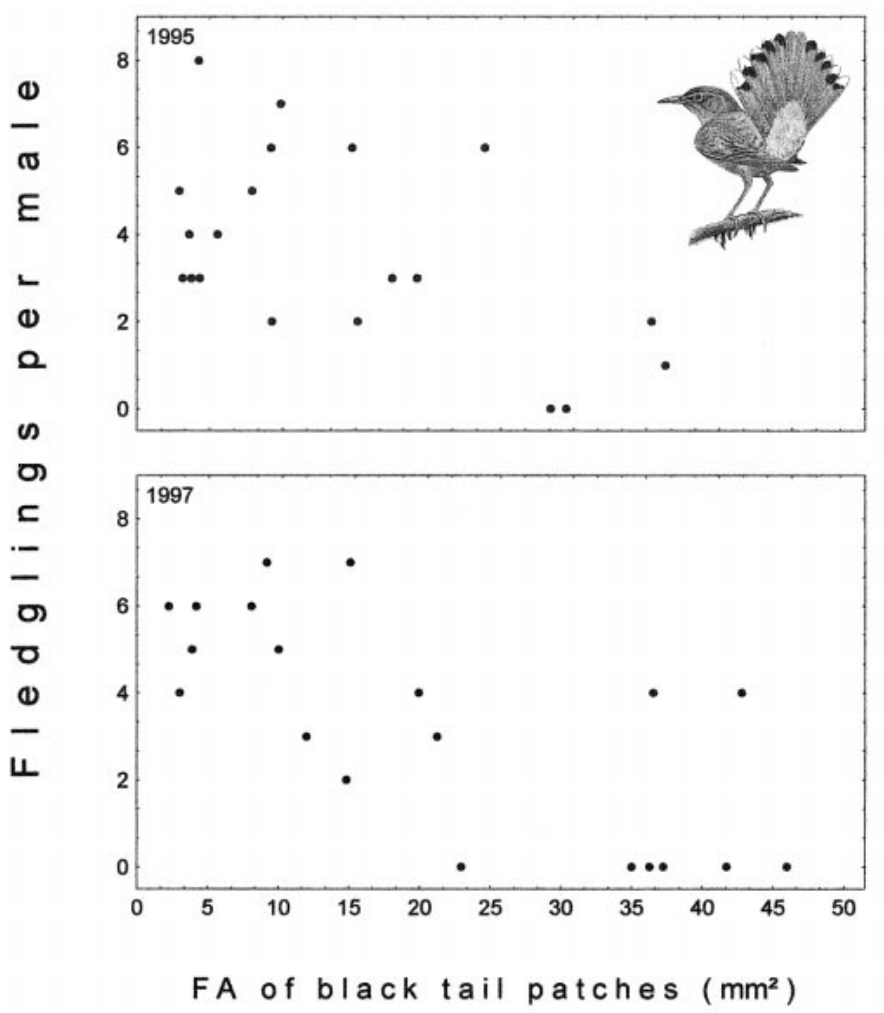

FIGURE 1. Fluctuating asymmetry (FA) of subterminal tail black patches and number of fledglings produced by each Rufous Bush Chat male in 1995 and 1997.

incubates. Social monogamy is the norm, and the pair remains together for the season. Second clutches are common, and replacement clutches are frequent, due to predation (average of $39 \%$ in a 6-year period in the study area), so that up to six successive nesting and laying attempts by the same pair after nest predation have been observed.

It is not possible to distinguish 1-year-old birds from older birds, and there is no information available on differences in the pattern of the tail patches or in any other feature between ages.

The aim of this study was to estimate the relationship between the visual tail features and reproductive success, date of mate acquisition, and incidence of nest predation in Rufous Bush Chats.

\section{METHODS}

The study area, about $20 \mathrm{~km}$ to the southeast of the city of Seville, Spain $\left(37^{\circ} 9^{\prime} \mathrm{N}, 2^{\circ} 14^{\prime} \mathrm{W}\right)$, is mostly used for intensive vineyard agriculture (vine stocks $1-1.5 \mathrm{~m}$ high, where Rufous Bush Chats build their nests), with orchards, interspersed fruit trees, and areas of kitchen gardens and vegetable growing. The climate is Mediterranean, with dry and hot summers, wet autumns and springs, and mild winters.

The study was undertaken during the reproductive seasons of 1995 and 1997 and extended from the mid- dle of April to the end of August. As males arrived to the breeding area, and before pairs were formed, they were attracted toward a recorded song and a stuffed Rufous Bush Chat decoy and caught in mist nets. Immediately after being captured, they were measured and banded with a steel ring and a unique combination of two plastic rings, and all information on their tail features was obtained. Body and tail features were remeasured by one of two persons, different from the one who took the first measure. Females are very secretive in the early phases of reproduction and were therefore not captured. Of the 28 and 35 males caught in 1995 and 1997, respectively, reproductive success and number of active and depredated nests of 20 mated males in 1995 and another 20 different males in 1997 were monitored ( 2 males in 1995 and 5 males in 1997 whose nests were parasitized by Cuckoos were discarded from the analysis). Of those males, the exact day of laying of the first egg in the first clutch was known for 18 males in 1995 and 16 males in 1997. The age of the subjects was unknown.

Tail features were analyzed with respect to (1) male reproductive success: number of fledglings produced by each male for the whole season, (2) date of first egg laid: number of days from the day before the laying of the first egg in the first male's nest, and (3) the proportion of depredated nests: number depredated di- 
vided by number of active nests (a nest was considered to be depredated if all eggs or nestlings disappeared).

Four tail features were measured: (1) tail length, total area of (2) terminal white patches, and (3) subterminal black patches, and (4) fluctuating asymmetry (FA) in the area of black tail patches (difference between sums of right and left sides).

Tail length (measured with calipers, to the nearest $0.01 \mathrm{~mm}$ ) was the length of the longest tail feather (the longer of the two central tail feathers). Total area of white and of black tail patches (in $\mathrm{mm}^{2}$ ) was the sum of the 8 white and of the 10 black tail patches, respectively. To obtain area values, the patches were outlined with a thin pen on transparent plastic sheets. The outlines were scanned and the area of each one was calculated with the aid of Sigmascan software for Windows (Jandel Corporation, San Rafael, California). In relation to FA in the patch area, area difference between sum of patch areas (white and black separately) of right and left sides of the tail were obtained: only area difference of black patches, not white patches, conformed to a FA pattern, and because the area difference |Right - Left| obtained for the black patches did not change with their total area, the FA index used for this character is $|\mathrm{R}-\mathrm{L}|$ (Palmer 1994).

In order to detect a potential relationship between the analyzed tail features and body reserves, an index of individual condition was calculated: body weight $x$ tarsus length $^{-3}$ for each male (with portable electronic balance and calliper, to the nearest $0.01 \mathrm{~g}$ and 0.01 $\mathrm{mm}$, respectively) (Brown 1996). The repeatability of body measures and of the tail features (including FA of black tail patches) was high (intraclass correlations not lower than $0.93 ; P<0.001$ in all cases).

The study area was inspected every two days for new nests, number and condition of eggs or chicks, which male was "in charge" of each nest, whether the nest was successful or not, and the number of fledglings, if any, "flying from" each nest. From this information, the proportion of depredated nests and the total seasonal reproductive success were obtained for each male.

The relationship of tail features with male reproductive success, date of laying of first egg, and with the proportion of depredated nests was estimated with multiple linear regression in separate analysis for each year. When the analyzed model was statistically significant, the step-down backward elimination procedure was applied (Zar 1996).

The distribution of FA of black patches was normalized according to Swaddle et al. (1994). The transformation used was $\left(\mathrm{Y}+\left(\lambda_{2}\right)^{\lambda_{1}}\right.$, where $\lambda_{1}$ is 0.3 and $\lambda_{2}$ is the value of the smallest asymmetry minus one $(P>0.2$, Kolmogorov-Smirnov test). The proportion of depredated nests was arcsin transformed and the remainder variables transformed by $\log _{10}(X+1)$; none of the transformed variables deviated significantly from a normal distribution.

\section{RESULTS}

In relation to male reproductive success, multiple regression of the four tail features on the total number of fledglings produced by males in a season was significant in both years (1995: $F_{4,15}=3.2, n=20, P<$
0.05; 1997: $\left.F_{4,15}=8.0, n=20, P<0.001\right)$. The stepdown elimination procedure showed a significant relationship with FA of subterminal tail black patches in $1995\left(F_{4,18}=9.3, n=20, P<0.01\right)$, and FA of subterminal tail black patches and total area of terminal white tail patches in $1997\left(F_{4,17}=13.3, n=20, P<\right.$ 0.001 ) (1995: $\log _{10}$ [number of fledglings] $=1.38-$ 0.58 standardized [FA of black tail patches]; 1997: $\log _{10}$ [number of fledglings] $=-8.40-0.45$ standardized [FA of black tail patches] $+0.41 \log _{10}$ [area of white tail patches]). Apparently, males attain greater reproductive success the smaller the FA of their tails' black patches and the larger the total area of the white tail patches (Fig. 1).

Date of first egg laid (and presumably of mate acquisition) also was significantly dependent on the tail features in the two study periods (1995: $F_{4,13}=7.7, n$ $\left.=18, P<0.003 ; 1997: F_{4,11}=3.4, n=16, P<0.05\right)$, and more specifically with FA of black tail patches in the two years of study, and with tail length in one year (1995: $\log _{10}$ [date of first egg laid] $=19.1+0.76$ standardized [FA of black tail patches] $-0.34 \log _{10}$ [tail length]; 1997: $\log _{10}$ [date of first egg laid] $=0.84$ +0.65 standardized [FA of black tail patches]).

Immediately after suffering nest predation, Rufous Bush Chats usually start a new nest. As a result, the number of active nests for each male varied from 1 to 6 (successive) nests in 1995 and from 1 to 4 in 1997 , and the number of depredated nests from 0 to 4 in both years. The multiple regression of the four tail features on the proportion of depredated to active nests also produced significant results, similar to those obtained for reproductive success (1995: $F_{4,15}=2.9, n=$ 20, $\left.P=0.05 ; 1997: F_{4,15}=13.6, n=20, P<0.001\right)$ [1995: $\arcsin$ (proportion of depredated nests) $=-1.10$ + 0.62 standardized (FA of black tail patches); 1997: $\arcsin$ (proportion of depredated nests) $=15.92+0.49$ standardized (FA of black tail patches) $-0.44 \log _{10}$ (area of white tail patches)].

Reproductive success was strongly related to date of laying of the first egg in one of the two years of study (1995: $r_{\mathrm{s}}=-0.67, n=18, P<0.003 ; 1997: r_{\mathrm{s}}=$ $-0.33, n=16, P=0.22)$, and with the proportion of depredated nests in the two years of study (1995: $r_{\mathrm{s}}=$ $-0.55, n=20, P<0.013 ; 1997: r_{\mathrm{s}}=-0.84, n=20$, $P<0.001)$. Thus, the lower the nest predation and (with less certainty) the earlier the mating, the higher the male reproductive success.

The analyzed tail features did not correlate with each other at a significant level, except for total area of white patches vs. FA of black patches (Table 1). Correlations between the analyzed tail features and condition (body weight $\times$ tarsus length ${ }^{-3}$ ) were nonsignificant (Table 1).

\section{DISCUSSION}

Of the analyzed tail features, FA of the subterminal black patches shows the highest relationship with seasonal male reproductive success, date of mate acquisition, and with proportion of depredated nests. A significant relationship was found between tail length and date of mate acquisition, and between total area of the white terminal patches with male reproductive success, and with proportion of depredated nests. 


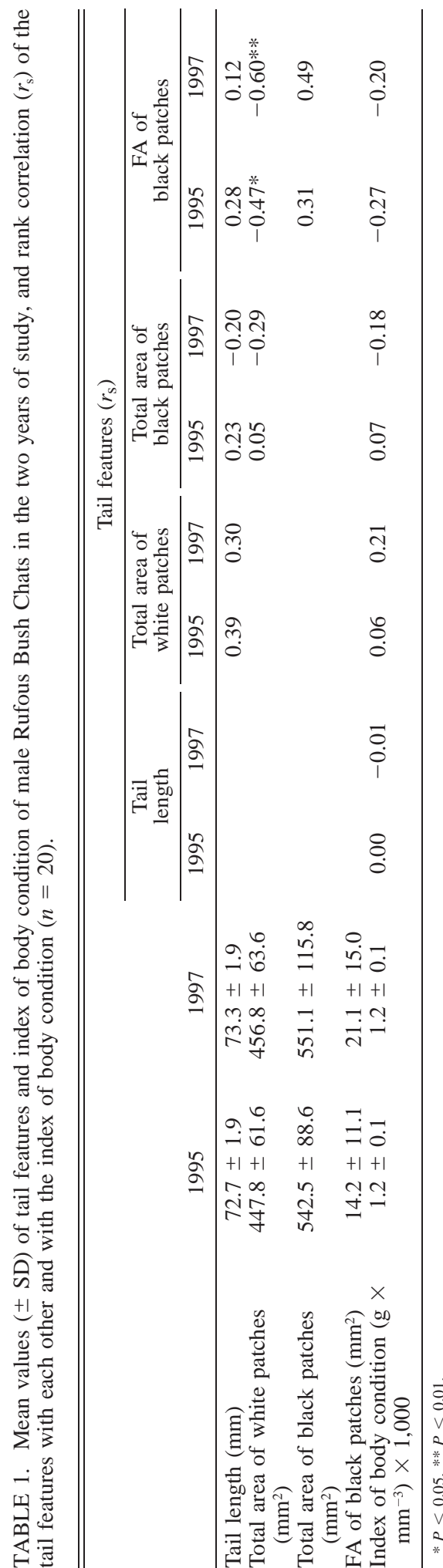

Perhaps a way to understand how these features may function is to consider that during the tail display (which occurs from less than $1 \mathrm{~m}$ up to $50 \mathrm{~m}$ from the receiver), the total area of the white patches contributes to conspicuousness, more so if we consider that the rest of the plumage coloration of Rufous Bush Chats is cryptic, and the presence of adjacent black patches is adding to contrast. A longer tail would obviously render those two features more visible.

As high reproductive success in our subjects appears related to early mating and to low proportion of depredated nests, and both variables are highly related to FA, we cannot determine which of the two is being affected by FA in the color pattern. The fact that the color patches are shown in tail display during aggressive encounters, courtship, and nest defense does not clarify whether the symmetric color pattern plays a role in sexual selection and/or diminishing nest predation.

If female choice of males with symmetrical visual tail-features occurs in Rufous Bush Chats (as is the case in other birds: Møller 1992, 1993, Swaddle and Cuthill 1994a, 1994b, Bennet et al. 1996, Fiske and Amundsen 1997), its straightforward nature (Wittenberger 1983) would be less time-consuming than if the choice would be based on a set of criteria. Time is apparently important, as early arrival to the breeding area and early mating usually contribute positively to reproduction in Rufous Bush Chats (present study) and other passerines (Lozano et al. 1996, Nyström 1997).

If females preferred symmetry in coloration, its function signaling high levels of developmental stability (Møller and Swaddle 1997) could provide the receiver with a nondeceptive signal of individual genetic quality, with no obvious costs to the sender.

In relation to nest predation, for FA in the contrasting black patches to be effective, it should function to attract the potential predator towards the bird (and away from the nest) during the distraction display, more easily than if the pattern were not symmetric. The Common Cuckoo, besides being a brood parasite of Rufous Bush Chats (Alvarez 1994a), also is a common predator of their nests, as well as a frequent receiver of their attacks and distraction displays (Alvarez 1994b). Among the potential nest predators in the study area (horseshoe snakes Coluber hippocrepis, Montpellier snakes Malpolon monspessulanus, ocellated lizards Lacerta lepida, weasels Mustela nivalis, domestic cats, and dogs), the Cuckoo is probably the only one with sufficient visual acuity to pay special attention to color patterns.

If predators are sensitive to very small asymmetries (Møller and Swaddle 1997), symmetric signals of contrast, combined with high conspicuousness in the tail display of Rufous Bush Chats, could perhaps attract them more easily towards the displaying bird. Both high conspicuousness and symmetric contrast, sometimes exhibited at very close range, could act together as a deflective mark (Cott 1940), attracting the predator and luring it away from the nest.

The pattern of erosion of the tail feathers supports the idea that conspicuous and contrasted black and white pattern and tail length help males to acquire a mate and/or lure predators away from the nest. The more intense abrasion of the apical white patches, 
some of them even vanishing at the end of the breeding season, is obviously related to their reduced resistance to abrasion, as they contain no melanin (Burtt 1979). In contrast, the melanin-protected black patches are hardly eroded. As a consequence, the apical white patches become smaller, and the tail length, as well as the conspicuousness of the whole pattern, are reduced at a time when they are not needed in mate acquisition and nest defense.

The fact that males in good condition are not better equipped with respect to the tail features related to reproduction may be the result of the index of condition used (body weight $\mathrm{x}$ tarsus length ${ }^{-3}$ ), which primarily measures body fat. Fat reserves should not be related to the potential to grow tail feathers (lack of relationship with tail length) or to the color pattern (total area of white patches and FA of black patches). Lack of a relationship of a similar index of body condition with FA of tail length and of other ornamental and non-ornamental traits also was found for the Red Junglefowl (Gallus gallus) by Kinball et al. (1997).

I thank M. Vázquez, B. Arrizabalaga, José and Juan Ayala, and J. Bernal for help in the field, and E. Aguilera, J. A. Amat, J. Cuervo, and T. Redondo for helpful comments. Financial support was provided by DGICYT (PB95-0110) and Junta de Andalucía (RNM 0105).

\section{LITERATURE CITED}

Alvarez, F. 1994a. A gens of Cuckoo Cuculus canorus parasitizing Rufous Bush Chat Cercotrichas galactotes. J. Avian Biol. 25:239-243.

Alvarez, F. 1994b. Cuckoo predation on nests of nearest neighbours of parasitized nests. Ardea 82: $269-270$.

Alvarez, F. 1996. Variation in the song rate during the breeding cycle of the Rufous Bush Chat, Cercotrichas galactotes. Ardeola 43:49-56.

Alvarez, F. 1997. The functions of song and the spatial pattern of song production in the Rufous Bush Chat (Cercotrichas galactotes). Doñana, Acta Vert. 24:67-78.

ANDERSSON, M. 1982. Female choice selects for extreme tail length in a widowbird. Nature 299:818-820.

Andersson, M. 1994. Sexual selection. Princeton Univ. Press, Princeton, NJ.

BAKer, R. R., AND G. A. PARKer. 1979. The evolution of bird coloration. Phil. Trans. R. Soc. Lond. B 287:63-130.

BARnARD, P. 1990. Male tail length, sexual display intensity and female sexual response in a parasitic African finch. Anim. Behav. 39:652-656.

Bennett, A. T. D., I. C. Cuthill, J. C. Partridge, And E. J. MAIER. 1996. Ultraviolet vision and mate choice in zebra finches. Nature 380:433-435.

Brown, M. E. 1996. Assessing body condition in birds. Current Ornithol. 13:67-135.

BuRTt, E. H. 1979. Tips on wings and other things, p. 75-110. In E. H. Burtt [ED.], The behavioral significance of color. Garland STPM Press, New York.

Cotт, H. B. 1940. Adaptive coloration in animals. Methuen, London.
Cramp, S. 1988. The birds of the Western Palearctic. Vol. 5. Oxford Univ. Press, Oxford.

Fiske, P., AND T. Amundsen. 1997. Female bluethroats prefer males with symmetric colour bands. Anim. Behav. 54:81-87.

FitzPatrick, S., And P. Price. 1997. Magpie tails: damage as an indicator of quality. Behav. Ecol. Sociobiol. 40:209-212.

Keith, S., E. K. Urban, and C. H. Fry. 1992. The birds of Africa. Vol. IV. Academic Press, London.

Kinball, R. T., J. D. Ligon, and M. Merola-ZwaRTJES. 1997. Fluctuating asymmetry in Red Junglefowl. J. Evol. Biol. 10:441-457.

Kose, M., AND A. P. MøLler. 1999. Sexual selection, feather breakage and parasites: the importance of white spots in the tail of the Barn Swallow (Hirundo rustica). Behav. Ecol. Sociobiol. 45:430-436.

López I., G. 1983. Datos sobre la nidificación del alzacola (Cercotrichas galactotes). Alytes 1:373392.

Lozano, G. A., S. Perreault, and R. E. Lemon. 1996. Age, arrival date and reproductive success of male American Redstart Setophaga ruticilla. J. Avian Biol. 27:164-170.

MøLler, A. P. 1988. Female choice selects for male sexual tail ornaments in the monogamous swallow. Nature 332:640-642.

MøLleR, A. P. 1992. Female swallow preference for symmetrical male sexual ornaments. Nature 357: 238-240.

MøLler, A. P. 1993. Female preference for apparently symmetrical male sexual ornaments in the Barn Swallow Hirundo rustica. Behav. Ecol. Sociobiol. 32:371-376.

Møller, A. P., ANd J. P. Swaddle. 1997. Asymmetry, developmental stability, and evolution. Oxford Univ. Press, Oxford.

Nyström, K. G. K. 1997. Food density, song rate, and body condition in territory-establishing Willow Warblers (Phylloscopus trochilus). Can. J. Zool. 75:47-58.

PALMER, A. R. 1994. Fluctuating asymmetry analyses: a primer, p. 335-364. In T. A. Markow [ED.], Developmental instability: its origins and evolutionary implications. Kluwer Academic Publishers, Dordrecht, Netherlands.

PÄrt, T., AND A. QVARnStröm. 1997. Badge size in Collared Flycatchers predicts outcome of male competition over territories. Anim. Behav. 54: 893-899.

Swaddle, J. P., And I. C. Cuthill. 1994a. Female zebra finches prefer males with symmetric chest plumage. Proc. R. Soc. Lond. B 258:267-271.

Swaddle, J. P., And I. C. Cuthill. 1994b. Preference for symmetric males by female zebra finches. Nature 367:165-166.

Swaddle, J. P., M. S. Witter, And I. C. Cuthill. 1994. The analysis of fluctuating asymmetry. Anim. Behav. 48:986-989.

WitTenberger, J. F. 1983. Tactics of mate choice, p. 435-447. In P. Bateson [ED.], Mate choice. Cambridge Univ. Press, Cambridge.

ZAR, J. H. 1996. Biostatistical analysis. Prentice Hall, Upper Saddle River, NJ. 